\title{
SISTEM INFORMASI GEOGRAFIS PEMETAAN TEMPAT WISATA DI KOTA SAMARINDA BERBASIS WEB
}

\author{
Liza Chairunnisa \\ Politeknik Pertanian Negeri \\ Samarinda \\ Teknologi Rekayasa Perangkat \\ Lunak, Manajemen Pertanian \\ Samarinda, Indonesia \\ lizachairunnisa33@gmail.com
}

\author{
Wahyuni Eka Sari \\ Politeknik Pertanian Negeri \\ Samarinda \\ Teknologi Rekayasa Perangkat \\ Lunak, Manajemen Pertanian \\ Samarinda, Indonesia \\ wahyunisari52@gmail.com
}

\author{
Dawamul Arifin \\ Politeknik Pertanian Negeri \\ Samarinda \\ Teknologi Rekayasa Perangkat \\ Lunak, Manajemen Pertanian \\ Samarinda, Indonesia \\ dawam.arifin00@gmail.com
}

\begin{abstract}
Abstrak-Penelitian ini dilatarbelakangi oleh belum terpublikasikan dengan baik tempat - tempat wisata yang ada di Kota Samarinda, sehingga wisatawan mampu mencari tempat - tempat wisata rekreasi dan kuliner yang terdapat di seputaran kota. Oleh karna itu tujuan dari penelitian ini adalah untuk membuat sistem informasi pemetaan wisata di Kota Samarinda, sehingga dapat mudah di akses oleh wisatawan dan masyarakat. Selain itu menyajikan informasi pemetaan dan lokasi wisata di Kota Samarinda, sistem yang di bangun bertujuan memperkenalkan kepada wisatawan tentang wisata rekreasi dan kuliner di Kota Samarinda dan memudahkan wisatawan untuk mencari tempat wisata rekreasi dan kuliner yang ada di Kota Samarinda sendiri. Hasil Penelitian ini diharapkan menunjukan bahwa sistem ini dapat digunakan sedemikian rupa untuk mengetahui letak tempat kuliner yang ada.
\end{abstract}

Kata Kunci - Sistem Informasi, Geografis, Pemetaan Wisata

\section{PENDAHULUAN}

Wisata merupakan kegiatan yang hampir semua orang pernah lakukan, bahkan tidak sedikit yang sangat menggemari kegiatan tersebut. Wisata berarti bepergian bersama-sama dan lebih diidentikkan dengan pergi keluar atau tamasya. Di Indonesia sendiri wisata sudah bukan hal yang asing lagi kedengarannya, ditambah lagi Indonesia sangat kaya akan tempat tujuan wisata yang sudah terkenal baik di dalam negeri maupun mancanegara. Wisata dalam bahasa Inggris disebut tour yang secara etimologi berasal dari kata torah (ibrani) yang berarti belajar, tornus (bahasa latin) yang berarti alat untuk membuat lingkaran dan dalam bahasa Perancis kuno disebut tour yang berarti mengelilingi sirkuit. Pada umumnya orang memberi padanan kata wisata dengan rekreasi, wisata adalah sebuah perjalanan, namun tidak semua perjalanan dapat dikatakan wisata (Suyitno, 2001).

Salah satu kota di Indonesia yang juga memiliki beberapa tempat wisata didaerahnya yaitu Samarinda, yang memiliki banyak tempat tujuan wisata mulai dari wisata alam, bahari, sejarah, kuliner, maupun lainnya yang cukup menarik wisatawan. Dengan banyaknya tempat tujuan wisata di Samarinda sayangnya tidak diimbangi dengan pemberian informasi yang cukup untuk wisatawan mengenai tempat tujuan wisata, sehingga dapat dibuatkan sebuah peta lokasi yang berisi tempat wisata yang ada di Samarinda.

Pemetaan lokasi wisata merupakan penyajian informasi akurat yang terkait dengan keberadaan suatu daerah tujuan wisata di suatu wilayah. Peta lokasi daerah tujuan wisata sangat diperlukan untuk dijadikan pedoman bagi wisatawan yang akan berkunjung ataupun dijadikan salah satu media untuk mempromosikan daerah tujuan wisata yang akan dikunjunginya. Salah satu bentuk penyajian informasi pariwisata itu adalah melalui penayangan dalam bentuk data atau informasi secara visualisasi yang dikaitkan dengan kondisi geografis suatu wilayah. Sistem ini sering dikenal dengan Sistem Informasi Geografis (SIG). Dengan SIG secara umum akan memberikan informasi yang mendekati kondisi dunia nyata dan dapat memprediksi suatu hasil, karena SIG akan menampilkan informasi mengenai tempattempat dipermukaan bumi dan informasi mengenai keterangan-keterangan (atribut) yang terdapat dipermukaan bumi sehingga dapat menampilkan kondisi seperti kondisi yang sebenarnya salah satunya kondisi lokasi objek wisata. penyajian tentang kepariwisataan di Kota Samarinda yang dikelola oleh Dinas Kebudayaan, Pariwisata Kota Samarinda pada saat ini adalah masih disajikan dalam bentuk leaflet, booklet, brosur-brosur, website dan promosi dengan mengikuti berbagai pameran baik yang di selenggarakan Kota Samarinda maupun Provinsi Kalimantan Timur maupun wilayah lain setiap tahunnya, jadi setiap masyarakat yang ingin mengetahui tentang objek wisata atau ingin mendapatkan leaflet, booklet, brosur- brosur, website tentang objek-objek wisata yang ada di Kota Samarinda tersebut dapat dilakukan dengan datang ke pameran atau datang secara langsung Kedinas Kebudayaan, Pariwisata Kota Samarinda tersebut. Selain itu website tentang info wisata yang di kelola belum berjalan maksimal. Dengan media promosi seperti ini dipandang belum memberikan efisiensi waktu dan kecepatan dalam mempromosikan objek-objek wisata tersebut kepada masyarakat. 
Berdasarkan latar belakang diatas, maka dapat diambil suatu permasalahan yang terkait dengan informasi tempat wisata yaitu bagaimana membuat aplikasi pemetaan obyek wisata di Samarinda berbasis web.

\section{TINJAUAN PUSTAKA}

\section{A. Kajian Ilmiah}

Beberapa literature yang digunakan sebagai pedoman dan acuan dalam skripsi ini diantara lain :

Penelitian yang dilakukan oleh Karman dan Riasanti (2017). Yang berjudul Perancangan Sistem Informasi Geografis Pemetaan Objek Wisata Di Kota Lubuklinggau Berbasis Web. Sistem ini membahas tentang dirancangnya sistem informasi geografis yang menarik dalam bidang kepariwisataan di Kota Lubuklinggau yang mampu memberikan informasi bagi masyarakat luas, mampu menampilkan peta, dan mampu menyimpan data. Penelitian ini menghasilkan sebuah Sistem Informasi Geografis Objek Wisata dikota lubuklinggau berbasis web yang didalamnya terdapat lokasi wisata, rute menuju wisata, informasi untuk mengetahui lokasi sekaligus informasi tentang daerah obyek wisata yang akan dikunjungi sebagai media alternatif untuk menginformasikan pariwisata di Kota Lubuklinggau agar bisa dinikmati masyarakat luas yaitu dengan melalui fasilitas internet. (Karman dan Riasanti, 2017).

Penelitian yang dilakukan oleh Tumimomor (2013). Yang berjudul Sistem Informasi Geografis Pariwisata Kota Kupang. Pembuatan Sistem informasi geografis ini ditujukan untuk para wisatawan yang kesulitan dalam mencari lokasi wisata dan kuliner yang ada dikota Kupang yang dibangun pada sistem berbasis web ini. Diharapkan menjadi sebuah alternatif sebagai media untuk informasi persebaran lokasi wisata dan kuliner dikota Kupang, selain itu juga untuk melakukan promosi pariwisata dan pelayanan pariwisata kepada masyarakat umum, didalam sistem terdapat informasi jenis wisata, lokasi wisata serta fasilitas wisata terdapat juga informasi tambahan seperti informasi hotel dan travel yang ditawarkan kepada masyarakat. Sistem ini juga menyajikan informasi berita mengenai kegiatan pariwisata yang ada di wilayah kota Kupang maupun di luar Wilayah kota Kupang yang masih tercakup daam provinsi Nusa Tenggara Timur (Tumimomor, 2013).

Penelitian yang dilakukan oleh Minarni dan Yusdi (2015). Yang berjudul Sistem Informasi Geografis Pariwisata Kota Padang. Sistem ini membahas tentang pemetaan tempat wisata menggunakan Google Maps API dapat menyediakan informasi seperti objek wisata, restoran, akomodasi, dan lainnya, jalan yang menghubungkan tempat-tempat tersebut, maupun deskripsi tentang tempat dan jalan dengan demikian wisatawan mempunyai panduan yang cepat dan akurat untuk membantu perjalanan di kota Padang (Minarni \& Yusdi, 2015).

Penelitian yang di lakukan oleh Ikhsan (2018) yang berjudul Sistem Informasi Geografis Pemetaan Wisata
Kuliner Kota Samarinda Berbasis Web sistem ini membahas tentang pemetaan wisata kuliner yang menggunakan Google Maps API dapat menyajikan informasi tempat wisata kuliner di kota tersebut dan untuk memudahkan wisatawan mencari tempat kuliner yang terdapat di Kota Samarinda, selain menyajikan lokasi kuliner terdapat rute yang menujukan arah jalan menuju tempat kuliner yang dituju di Kota Samarinda (Ikhsan, 2018).

Berdasarkan dengan penelitian sebelumnya dari uraian jurnal atau penelitian tersebut, sistem yang akan dibuat yaitu dengan memanfaatkan teknologi Google Maps API sebagai media pemetaan lokasi tempat wisata yang ada pada kota Samarinda yang notabennya merupakan sebuah library javascript yang dimuat dengan cara menambahkan tag script pada sebuah halaman website yang bisa menampilkan sebuah peta digital pada halaman website.

Berikut ini merupakan tabel studi literatur yang dijelaskan pada Tabel 1:

Tabel 1. Studi Literatur

\begin{tabular}{|c|c|c|c|}
\hline No & Nama & Judul & Tahun \\
\hline 1 & $\begin{array}{l}\text { Karman dan } \\
\text { Riasanti }\end{array}$ & $\begin{array}{l}\text { Perancangan } \\
\text { Sistem Informasi } \\
\text { Geografis } \\
\text { Pemetaan Objek } \\
\text { Wisata Di Kota } \\
\text { Lubuklinggau } \\
\text { Berbasis Web }\end{array}$ & 2017 \\
\hline 2 & Tumimomor & $\begin{array}{l}\text { Sistem Informasi } \\
\text { Geografis } \\
\text { Pariwisata Kota } \\
\text { Kupang }\end{array}$ & 2013 \\
\hline 3 & $\begin{array}{l}\text { Minarni dan } \\
\text { Yusdi }\end{array}$ & $\begin{array}{l}\text { Sistem Informasi } \\
\text { Geografis } \\
\text { Pariwisata Kota } \\
\text { Padang }\end{array}$ & 2015 \\
\hline 4 & Ikhsan & $\begin{array}{l}\text { Informasi } \\
\text { Geografis } \\
\text { Pemetaan Wisata } \\
\text { Kuliner Kota } \\
\text { Samarinda } \\
\text { Berbasis Web }\end{array}$ & 2018 \\
\hline
\end{tabular}

\section{Sistem Informasi Geografis (SIG)}

Sistem Informasi Geografis adalah sistem informasi khusus yang mengelola data yang memiliki informasi spasial (bereferensi keruangan). Atau dalam arti yang lebih sempit, adalah sistem komputer yang memiliki kemampuan untuk membangun, menyimpan, mengelola dan menampilkan informasi bereferensi geografis, misalnya data yang diidentifikasi menurut lokasinya, dalam sebuah database (Riyanto, 2005).

Dari dunia nyata diambil tiga hal penting seperti diuraikan di atas yaitu posisi kasifikasi, atribut, serta hubungan antar item terebut. Ketiga hal tesebut diolah 
sebagai dasar analisa sistem spasial dalam SIG. dengan dasar tersebut maka dapat diperoleh manfaat dari SIG sebagai berikut:

a. Menjelaskan tentang lokasi atau letak

Lokasi atau tempat dapat dijelaskan dengan memberi keterangan tentang nama tempat tersebut, kode pos, kode wilayah, letak latitude / longitude, atau atribut lainnya. SIG menyimpat ini sebagai data atribut dan digambarkan secara spatial.

b. Menjelaskan kondisi ruang

Ruang yang disebut adalah tempat tertentu dengan satu atau beberapa syarat tertentu. Dalam hal ini penentuan lokasi ideal akan memperhatikan syarat-syarat kesesuaian untuk pemukiman tersebut. Syarat-syarat kesesuaian ini menjadi indicator bagai SIG untuk menilai suatu kawasan memeiliki tingkat kesesuaian tertentu.

c. Menjelaskan suatu kecendrungan (trend)

Analisis dalam sistem informasi geografis dapat dilakukan secara multi temporal dengan menggunakan data multi temporal dengan menggunakan data multi waktu. Analisis ini akan memberi penjelasan tentag dengan pengambaran lokasi dimana fenomena tersebut akan terjadi.

d. Menjelaskan tentang pola spasial (spatial pattern)

Pola sebuah fenomena dapat dilhat dari sebarannya secara spasial. Sebuah kawasan dapat dilihat bentuk pola pemukimannya dengan melihat bagaimana sebaran rumah-rumah penduduk. Dengan mengetahui pola-pola suatu fenomena secara spatial, dapat dicari korelasi dengan fenomena lain seperti bentuk penyebaran, pola pengembangan wilayah, pembangunan sarana dan prasarana (Prahasta, 2005).

Sistem informasi geografis menyimpan semua informasi deskriptif unsur-unsurnya sebagai atribut-atribut di dalam basisdata. Kemudian, sistem informasi geografis membentuk dan menyimpannya di dalam tabel-tabel (relasional). Setelah itu, sistem informasi geografis menghubungkan unsur- unsur di atas dengan tabel-tabel yang bersangkutan. Dengan demikian, atribut-atribut ini dapat diakses melalui lokasi-lokasi unsur-unsur peta, dan sebaliknya unsur-unsur peta juga dapat diakses melalui atribut-atributnya. Karena itu, unsur-unsur tersebut dapat dicari dan ditemukan berdasarkan atribut-atributnya.

Sistem informasi geografis menghubungkan sekumpulan unsur-unsur peta dengan atribut-atributnya di dalam satuan-satuan yang disebut layer. sungai, bangunan, jalan, laut, batas-batas administrasi, perkebunan, dan hutan merupakan contoh-contoh dari layer. Kumpulan dari layer-layer ini akan membentuk basisdata sistem informasi geografis. Dengan demikian, perancangan basisdata merupakan hal yang esensial di dalam sistem informasi geografis. Rancangan basisdata akan menentukan efektifitas dan efisiensi proses-proses masukan, pengelolaan, dan keluaran sistem informasi geografis (Prahasta, 2002).

Sistem informasi Geografis memiliki perbedaan pokok dengan sistem informasi lain. Perbedaan ini menjadi ciri karakteristiknya pada sebuah sistem informasi selain SIG, basis data atributal adalah focus dari pekerjaan sistem, sedangkan SIG meningkakan data atributal dengan data spasial. Mengingat sumber data sebagian besar dari data peindraan jauh baik citra satelit maupun citra foto, maka teknologi sistem informasi geografis (SIG) erat kaitannya degan teknologi pengindraan jauh. Akan tetapi, pengindraan jauh bukanlah satu-satunya ilmu pendukung bagi sistem ini. Sumber data lain berasal dari hasil survei terrestrial (uji lapangan) dan data sekunder lain seperti sensus, catatan, dan laporan yan terpercaya. Secara diagram hal tersebut dapat dilihat pada Gambar 1.

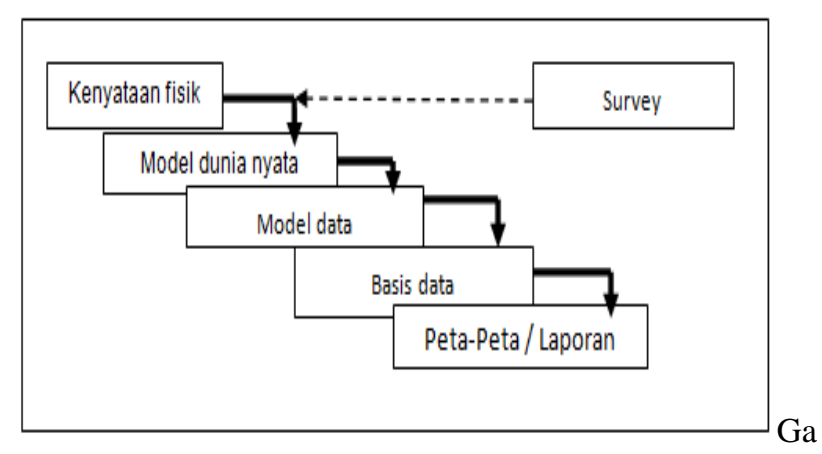

Gambar 1. Diagram Sumber Data (SIG)

Data spasial dari pengindaraan jauh adalah survei terrestrial tersimpan dalam basis data yang memanfatkan teknologi computer diital untuk pengelolan dan pengambilan keputusan (Budiyanto, 2004).

2. Komponen Sistem Informasi Geografis

Sistem Informasi Geografis terdiri dari beberapa komponen utama yang saling berinteraksi untuk merealisasikan suatu tujuan yang ingin dicapai. Komponen- komponen tersebut adalah sebagai berikut:

a. Perangkat Keras (Hardware)

Perangkat keras yang sering digunakan untuk SIG adalah komputer PC (Personal Computer). Perangkat keras tambahan berupa perangkat untuk pemasukan data (input) seperti scanner, digitizer, media penyimpanan data, dan perangkat untuk mencetak data (output) seperti layar monitor, printer dan sebagainya.

b. Perangkat Lunak (Software)

Perangkat lunak merupakan komponen untuk pengolahan basis data(database), pemrosesan dan analisa hasil keluaran (output). Saat ini sudah banyak perangkat lunak (software) yang dibuat untuk digunakan dalam proses pengolahan data (spasial dan non-spasial) pada SIG, antara lain: Arc View, Map Info, Arc GIS, SVG, Mysql, dan lain-lain.

c. Intelegensi Manusia (Brainware)

Brainware merupakan kemampuan manusia dalam membangun, mengelola, dan memanfaatkan SIG secara efektif. Selain itu diperlukan pula kemampuan untuk memadukan pengelolaan dengan pemanfaatan SIG, agar SIG dapat digunakan secara efektif dan efisien. Adanya koordinasi dalam pengelolaan SIG sangat diperlukan agar informasi yang diperoleh cepat, tepat, dan akurat.

\section{d. Data SIG}

Dapat mengumpulkan dan menyimpan data dan informasi yang diperlukan baik secara langsung maupun tidak langsung yaitu dengan cara meng-importnya dari 
perangkat lunak SIG, maupun secara langsung dengan cara mendigitasi data spasialnya dari peta dan memasukkan data atributnya dari tabel-tabel melalui keyboard. SIG merupakan perangkat analisis keruangan dengan kelebihan dapat mengelola data spasial dan data nonspasial sekaligus. Data atribut atau data non-spasial adalah gambaran data yang terdiri atas informasi yang relevan terhadap suatu lokasi, seperti kedalaman, ketinggian, lokasi penjualan dan lain - lain. Data spasial adalah data yang mempunyai referensi lokasi terhadap referensi tertentu. Jenis data spasial antara lain peta, foto udara, citra satelit atau data lain yang mempunyai referensi. Data spasial ini terbagi menjadi dua jenis data, yaitu data raster dan data vector (Prahasta, 2005).

\section{Google Maps API(application programming interface)}

API atau application programming interface adalah sekumpulan perintah, fungsi, dan protokol yang dapat digunakan oleh programmer saat membangun perangkat lunak untuk sistem operasi tertentu. Menurut web Google Maps for Bussines, Google Maps API adalah kumpulan API yang memungkinkan pengguna menghamparkan data pada Google Maps yang disesuaikan. Pengguna dapat membuat aplikasi web dan seluler menarik dengan platform pemetaan canggih dari Google termasuk basis data citra satelit, pemandangan jalan, profil ketinggian, petunjuk arah mengemudi, peta dengan sentuhan gaya, demografi, analisis, dan tempat yang luas.

Google Maps diperkenalkan pada Februari 2005 dan merupakan revolusi bagaimana peta di dalam web, yaitu dengan membiarkan user untuk menarik peta sehingga dapat menavigasinya. Solusi peta ini pada saat itu masih baru dan membutuhkan server khusus. Beberapa saat setelahnya, ada yang berhasil men-hack Google Maps untuk digunakan di dalam webnya sendiri. Hal ini membuat Google Maps mengambil kesimpulan bahwa mereka membutuhkan API dan pada Juni 2005, Google Maps API dirilis secara publik (Svennerberg, G. 2010).

\section{METODE PENELITIAN}

\section{A. Tempat dan Waktu}

Penelitian ini dilakukan di Kota Samarinda Kalimantan Timur sebagai objek yang dikaji. Penelitian ini dilakukan selama 7 bulan pada Desember 2018 sampai Juli 2019.

\section{B. Alat dan bahan}

Pengembangan sistem informasi ini menggunakan alat dan bahan spesifikasi hardware sebagai berikut:

1. Alat :

Alat yang digunakan adalah sebagai berikut:

1. Laptop

2. Sublime Text Editor

3. Software API(application programming interface)

4. XAMPP

5. Browser Google

6. HP Oppo F7
2. Bahan :

\section{Data Tempat Wisata}

\section{Prosedur Penelitian}

Tahapan pembuatan Sistem Informasi Geografis Pemetaan Tempat Wisata di Samarinda digunakan model waterfall. Model ini melakukan pendekatan secara sistematis atau secara berurutan dalam membangun suatu sistem. Diagram alur metodelogi penelitian ini ditunjukan pada Gambar 2.

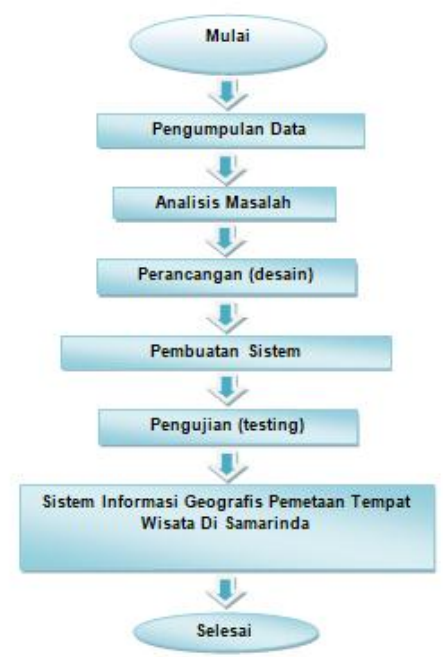

Gambar 2. Prosedur Penelitian

\section{Metode pengembangan}

Metode pengembangan sistem ini terdiri dari lima (5) tahap pengembangan yang penulis lakukan berdasarkan:

\section{Pengumpulan Data}

Mengumpulkan data dengan pergi kelapangan langsung dan data yang didapatkan dari Dinas Pariwisata Kota Samarinda. Menyusun secara sistematis mengenai data yang diperlukan seperti letak koordinat, tagging tempat atau lokasi wisata, dan catatan longitude, latitude.

\section{Analisis Masalah}

Analisis masalah merupakan penguraian dari suatu sistem infromasi yang utuh ke dalam bagian-bagian komponennya. Dengan maksud untuk mengidentifikasi dan mengevaluasi permasalah atau hambatan yang terjadi dan kebutuhan-kebutuhan yang di harapkan sehingga dapat perbaikan. Adanya kekurangan pada sistem yang sedang berjalan tersebut maka perlu ada suatu sistem yang memperbaiki sistem tersebut. Sistem yang di kembangkan ini tidak terlepas dari kebutuhan informasi yang diperlukan. Pengambilan data dilakukan dengan memarker lokasi tersebut dengan aplikasi GPS Coordinates.

\section{Perencanaan (Desain)}

Membuat desain sistem dalam perangkat keras (hardware). Mendefinisikan arsitektur sistem secara keseluruhan. Perancangan yang dilakukan baik dari DAD (Diagram Alir Data) dan basisdata. 


\section{Pembuatan sistem}

Penjelasan pembuatan sistem yang dilakukan adalah untuk membuat suatu aplikasi sistem informasi pemetaan dengan web yang berjalan dengan baik yaitu dengan langkah pertama sediakan peta dari google maps, website yang berisikan tentang tempat wisata, dan mengabungkan google maps dengan website sehinga menjadi suatu sistem informasi pemetaan berbasis web.

\section{Pengujian (Testing)}

Testing adalah pengujian yang dilakukan hanya mengamati hasil eksekusi melalui data uji dan memeriksa fungsional dari perangkat lunak. Jadi mengevaluasi hanya dari tampilan luarnya (interface), fungsionalitasnya saja tanpa mengetahui apa sesungguhnya yang terjadi di dalam proses detailnya (hanya melalui input dan output).

E. Rancangan Sistem

1. Berikut ini adalah DFD (Data Flow Diagram) level 0 , DFD terdiri dari 2 (dua) entity yaitu admin dan pengunjung. Admin memberikan input ke sistem berupa data kuliner dan data rekreasi. Pengunjung mencari data kuliner dan data rekreasi ke sistem. Kemudian google maps API digunakan untuk menimbulkan peta pada sistem. Dapat dilihat pada Gambar 3.

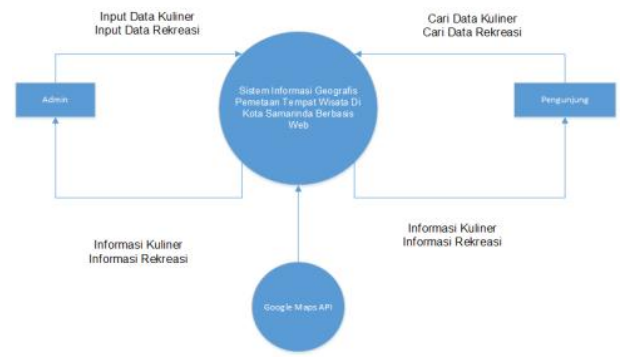

Gambar 3. DFD Level 0

2. Berikut ini adalah DFD (Data Flow Diagram) level 1, pada DFD level 1 ada 5 (lima) proses. Untuk yang pertama proses login dari admin, yang kedua proses admin mengatur isi tampilan beranda, selanjutnya proses admin mengatur atau mengubah koordinat peta wisata, kemudian proses admin menambah informasi tentang pembuat sistem. Untuk proses user yaitu mencari data lokasi pada lokasi peta. Proses Google maps API yaitu untuk menimbulkan peta di peta wisata. Dapat dilihat pada Gambar 4.

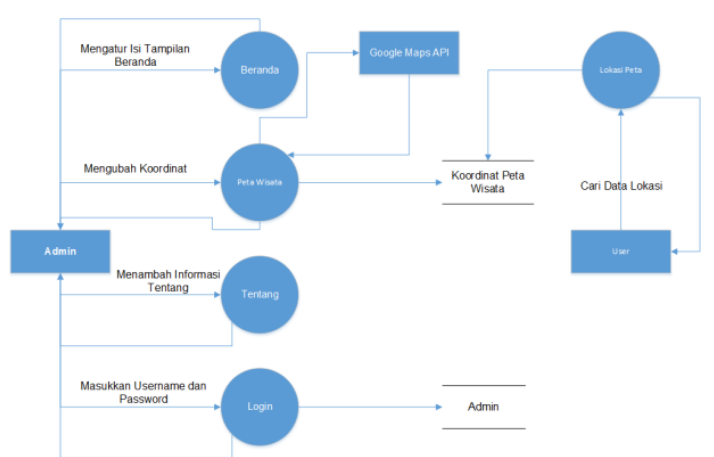

Gambar 4. DFD Level 1

\section{F. Rancangan Database}

Pada rancangan database yang dipaparkan di bawah terdapat dua tabel. Tabel. 2 wisata yang berisi field id, latitude, longitude, nama_tempat, alamat, info, kontak dan foto. Dan table. 3 user yang berisi field username dan password. Dari rancangan tersebut pengguna mendapatkan informasi tentang lokasi titik wisata dan informasi detail wisata.

Tabel 2. Tb_wisata

\begin{tabular}{cccc}
\hline Nama Fields & Tipe Data & Panjang & Keterangan \\
\hline Id & Int & 50 & PK AI \\
Latitude & Decimal & 10,7 & \\
Longitude & Decimal & 10,7 & \\
Nama_tempat & Varchar & 100 & \\
Alamat & Varchar & 225 & \\
Info & Varchar & 500 & \\
Kontak & Varchar & 100 & \\
Foto & Varchar & 100 & \\
\hline
\end{tabular}

Tabel 3. User

\begin{tabular}{cccc}
\hline Nama Fields & Tipe Data & Panjang & Keterangan \\
\hline Username & Varchar & 30 & \\
Password & Varchar & 30 & \\
\hline
\end{tabular}

\section{HASIL DAN PEMBAHASAN}

\section{A. Hasil}

Hasil dari aplikasi ini adalah pengguna dapat melihat tampilan halaman depan, setelah itu pengguna juga dapat melihat peta dan lokasi titik wisata di dalam peta ada button pencarian pengguna dapat mencari wisata rekreasi atau wisata kuliner yang ingin mereka tuju, setelah mencari. Pengguna juga dapat melihat info detail yang berisi tentang nama wisata, alamat wisata, info wisata, kontak wisata, dan foto wisata.

\section{Implementasi database}

Langkah pertama dalam membuat aplikasi adalah melakukan instalasi aplikasi server yaitu menggunakan Xampp control panel yang di install pada browser Google Chrome. Setelah selesai melakukan instalasi kemudian jalankan aplikasi Xampp control panel. Pada sistem yang telah dibangun database yang di dalamnya berisi tabel. Dapat dilihat pada Gambar 10. 


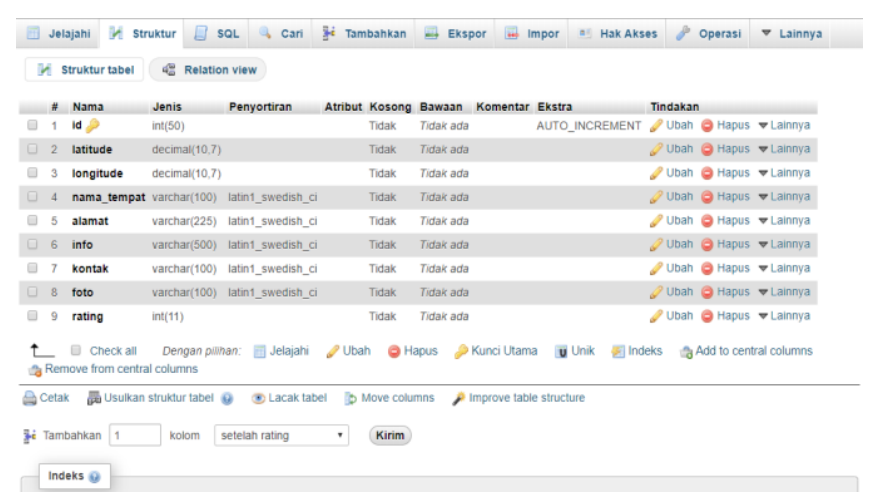

Gambar 5. Tabel Wisata

\section{Halaman Beranda}

Pada halaman beranda terdapat button menu berisi menu-menu yang terdapat pada aplikasi. Terdapat juga pengertian, sejarah-sejarah, dan juga destinasi wisata dan kuliner disamarinda. Dapat dilihat pada Gambar 11.

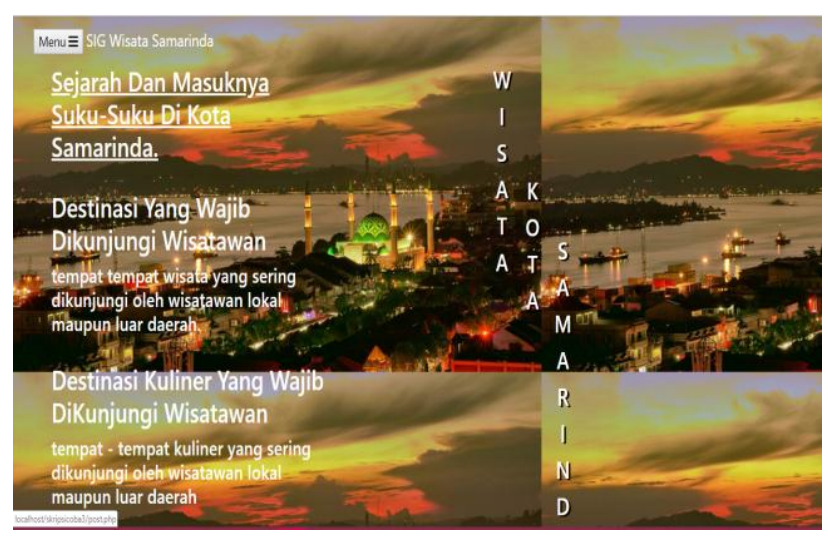

Gambar 6. Halaman Beranda

\section{Halaman Peta}

Berisi Peta dan marker wisata-wisata yang ada di samarinda. Dapat dilihat pada Gambar 12.

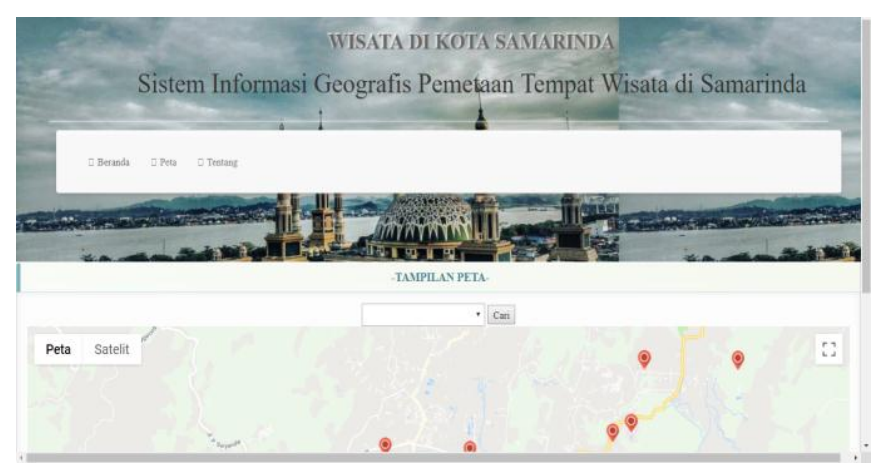

Gambar 7. Halaman Peta

\section{Halaman Tambah Data}

Pada halaman ini untuk mengisi data baru yang belum ada sebelumnya. Terdapat button simpan dan batal. Dapat dilihat pada Gambar 14.

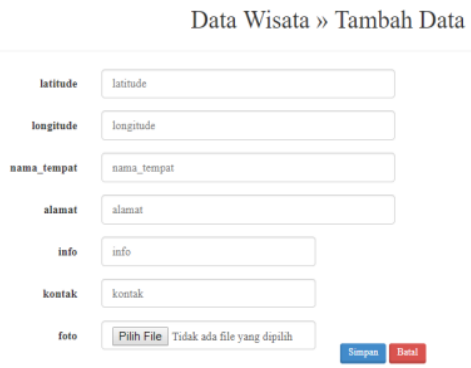

Gambar 8. Halaman Tambah Data

5. Halaman Edit

Halaman ini untuk mengedit data jika terdapat kesalahan data atau jika ingin mengupdate data. Dapat dilihat pada Gambar 15 .

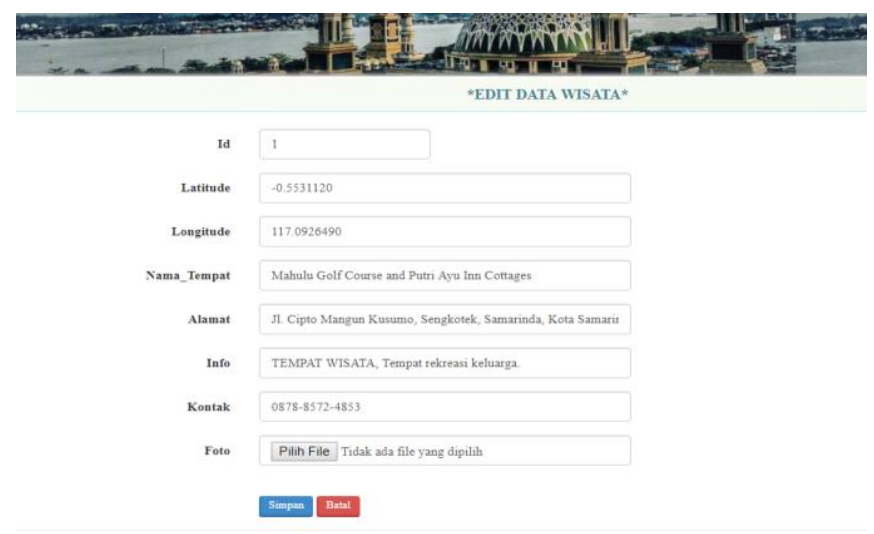

Gambar 9. Halaman Edit Data

6. Hapus Data

Pada halaman ini jika pengguna menekan tombol hapus akan muncul pemberitahuan hapus data. Dapat dilihat pada Gambar 16.

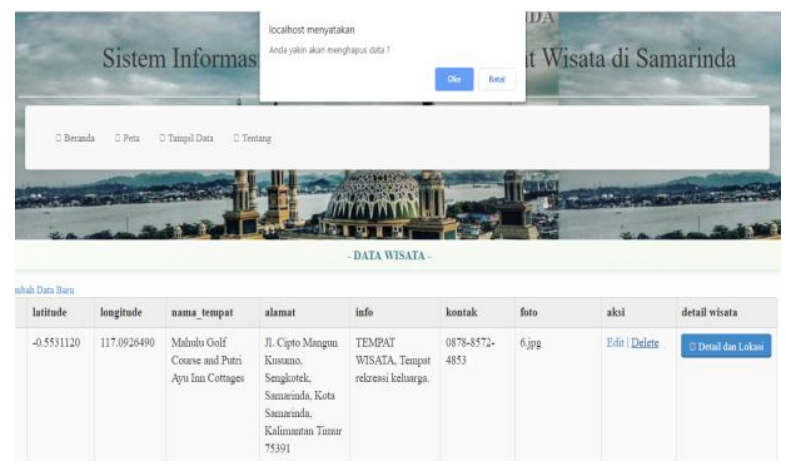

Gambar 10. Halaman Hapus Data

\section{Detail Lokasi}

Halaman ini menunjukan informasi detail lokasi reklame yang ada di kota samarinda. Dapat dilihat pada Gambar 17. 


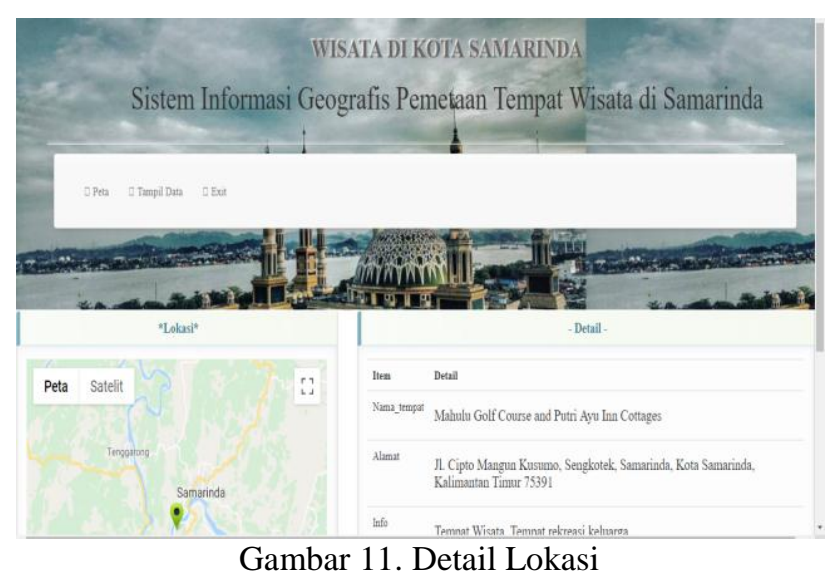

8. Halaman Tentang

Halaman ini berisikan tentang informasi biodata pembuat program. Dapat dilihat pada Gambar 18.

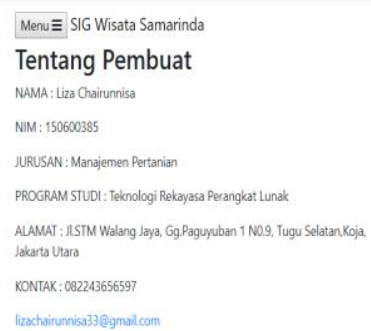

Gambar 12. Halaman Tentang

\section{B. Pembahasan}

Sistem ini dapat menampilkan tempat - tempat wisata rekreasi dan kuliner yang tersebar khususnya di Kota Samarinda, dan mampu menambah, menghapus, dan memperbaharui data jika data mengalami penambahan. Berikut pembahasan yang dapat di sampaikan:

1. Black Box Testing

Black Box Testing berfokus pada spesifikasi fungsional dari perangkat lunak. Tester dapat mendefinisikan kumpulan kondisi input dan melakukan pengetesan pada spesifikasi fungsional program. Black Box Testing bukanlah solusi alternatif dari White Box Testing tapi lebih merupakan pelengkap untuk menguji hal-hal yang tidak dicakup oleh White Box Testing. Hasil pengujian sistem ditunjukkan pada Tabel 4.

Tabel 4. Black Box Testing

\begin{tabular}{c|c|c}
\hline INPUT & OUTPUT & HASIL UJI \\
\hline $\begin{array}{c}\text { Klik menu } \\
\text { Beranda }\end{array}$ & $\begin{array}{c}\text { Menampilkan } \\
\text { halaman beranda }\end{array}$ & Berhasil \\
\hline $\begin{array}{c}\text { Klik menu Peta } \\
\text { Wisata }\end{array}$ & $\begin{array}{c}\text { Menampilkan } \\
\text { halaman peta }\end{array}$ & Berhasil \\
\hline $\begin{array}{c}\text { Klik kuliner di } \\
\text { pencarian }\end{array}$ & $\begin{array}{c}\text { Menampilkan } \\
\text { marker kuliner }\end{array}$ & Berhasil \\
\hline $\begin{array}{c}\text { Klik rekreasi di } \\
\text { pencarian }\end{array}$ & $\begin{array}{c}\text { Menampilkan } \\
\text { marker rekreasi }\end{array}$ & Berhasil \\
\hline Klik menu & Menampilkan & Berhasil \\
\hline
\end{tabular}

\begin{tabular}{c|c|c}
\hline Tentang & $\begin{array}{c}\text { halaman tentang } \\
\text { pembuat }\end{array}$ & \\
\hline Klik menu Login & $\begin{array}{c}\text { Menampilkan } \\
\text { halaman login admin }\end{array}$ & Berhasil \\
\hline Klik Tampil Data & $\begin{array}{c}\text { Menampilkan } \\
\text { halaman data-data } \\
\text { wisata }\end{array}$ & Berhasil \\
\hline Klik tambah data & $\begin{array}{c}\text { Menampilkan } \\
\text { halaman yang berisi } \\
\text { field untuk } \\
\text { menambah data }\end{array}$ & Berhasil \\
\hline Klik Edit & $\begin{array}{c}\text { Menampilkan } \\
\text { halaman yang berisi } \\
\text { field untuk mengedit } \\
\text { data }\end{array}$ & Berhasil \\
\hline Klik Delete & $\begin{array}{c}\text { Menampilkan pop up } \\
\text { konfirmasi untuk } \\
\text { menghapus data }\end{array}$ & Berhasil \\
\hline Klik Detail Lokasi & $\begin{array}{c}\text { Menampilkan } \\
\text { halaman yang berisi } \\
\text { detail lokasi wisata }\end{array}$ & Berhasil \\
\hline Klik Exit & $\begin{array}{c}\text { Kembali ke halaman } \\
\text { beranda awal }\end{array}$ & Berhasil \\
\hline
\end{tabular}

\section{KESIMPULAN}

Telah selesai dibuatnya sistem informasi geografis pemetaan tempat wisata di Kota Samarinda berbasis web yang mana dapat membantu penyampaian informasi lokasi-lokasi tempat wisata yang terdapat di Kota Samarinda. Sistem ini dapat memunculkan peta beserta marker lokasi wisata yang terdapat di Kota Samarinda.

Pengembangan aplikasi selanjutnya diharapkan dapat diimplementasikan menggunakan mobile ataupun android. Diharapkan pengembangan aplikasi ini dapat memberikan informasi jarak terdekat dari pengguna. Diharapkan pengembangan aplikasi ini pengguna dapat memasukkan data wisata terbaru.

\section{DAFTAR PUSTAKA}

Aprianti, R. 2015. Mengenal Apa Itu XAMPP? https://rantidiaapriyanti.wordpress.com ( diunduh 30 September 2018).

Baxter, R., Hastings, N., Law, A., \& Glass, E. J. . 2008. [MANAGEMENT INFORMATION SYSTEMS]. Animal Genetics (Vol. 39).

Budiyanto, E. 2004. Sistem Informasi Geografis Menggunakan MapInfo. YOGYAKARTA: ANDI.

Hidayatullah, P. dan Kawistara, J.K. 2014. Pemrograman Web Informatika Bandung, Bandung

Ikhsan, M. F. 2018. Kota Samarinda Berbasis Web Geographic Information System Mapping Of Culinary Tourism In The City Of Samarinda. Jermika Informatika, 1 .

Junirianto, E. 2012. Rancang Bangun Aplikasi Penjualan NoteBook Berbasis Web Service. Universitas Mulawarman.

Karman, J., Sistem, P., Geografis, I., Objek, P., Di, W., Lubuklinggau, K., \& Web, B. 2017. Perancangan Sistem Informasi Geografis Pemetaan Objek Wisata Di Kota Lubuklinggau Berbasis Web, 1(1). 
Mailany Tumimomor. 2013. Sistem Informasi Geografis Pariwisata Kota Kupang Oleh. Jurnal Nasional Pendidikan Teknik Informatika, 1, 142-152.

Minarni \& Yusdi, Y. F. 2015. Sistem Informasi Geografis Pariwisata Kota Padang Menggunakan Application Programming Interface (API) Google Maps Berbasis Web. Jurnal TEKNOIF, 3(1), 3137.

Prahasta, E. 2002. Konsep -Konsep Dasar Sistem Informasi Geografis. Informatika, Bandung.

Prahasta, E. 2005. Sistem Informasi Geografis : Tutorial Arcview. Bandung: Informatika.

Riyanto. 2005. Pengembangan Aplikasi Sistem Informasi Geografis Berbasis Desktop dan Web. Gava Media. YOGYAKARTA.

Syafitri, I. 2011. Pengertian PHP Beserta Fungsi dan Sejarah PHP Yang Wajib Anda Ketahui. https://www.nesabamedia.com/pengertian-php-danfungsinya/ (diunduh 15 Agustus 2019).

Tarmizi, H. 2017. Pengertian Sublime Text. https://hayantarmizi.blogspot.com. (diunduh 30 September 2018). 